\title{
Local-Dis-Connection: The Influence of Semarang-Solo Toll Road to Socio-Spatial Disintegration
}

\author{
Susiyowati Indah Ayuni ${ }^{1}, S$. Sariffuddin ${ }^{2}$ \\ ${ }^{1}$ Directorate of spatial management and planning, Ministry of agrarian affairs and spatial planning \\ ${ }^{2}$ Department of urban and regional planning, Faculty of Engineering, Diponegoro University, Semarang, Indonesia
}

\begin{abstract}
Development of a toll road infrastructure serves as a hub for growth centers and global connections, on the other side, this infrastructure development will instead break local connections and further marginalize lower-class society. Trying to prove the thought, this paper aims to analyze the impact of Semarang - Solo toll road construction on socio-spatial communities in Kandangan Village. This research utilizes livelihood asset variables in the form of social capital, human capital, financial capital, natural resource capital, and physical capital. The method used in this research is the analysis of settlement patterns utilizing GIS, and regression analysis that served to know the size of the socio-spatial disintegration that occurred after construction. The results show that the spatial impacts caused by toll road construction resulted in the physical changes of settlements in Kandangan Village which can be seen from the changes in settlement patterns between the period of 2011 and 2017. Meanwhile, the social impacts show the characteristics of the five livelihood assets that change after the construction of the toll road. The findings of this study indicate that Kandangan village experiences socio-spatial disintegration with moderate levels. Although Kandangan Village has a moderate socio-spatial disintegration level, it doesn't cause social conflict.
\end{abstract}

Keywords: disintegration; socio-spatial; livelihood asset; settlement pattern; toll road infrastructure.

\section{Introduction}

The toll road construction is an alternative from the government to smoothen the traffic flow in a developed region, to improve good and service distribution that supports the economic growth of a region, and to reduce the government's financial burden through road users' participation. According to Johansen [1] toll road is considered as an effective solution to solve congestion, redistribute income, and improve the gross domestic product of a region. Nowadays, more toll roads are constructed to connect cities with its neighboring areas [2]. The construction of a toll road based on Graham and Marvin [3] is a privatization effort on public infrastructure practiced by the developer or private party to accommodate medium to high-class vehicle owners. Toll road functions as the connector between the center of economic growth and it is to improve the global connection such as to broaden urban area, enhance good and service flow; yet it the other hand, infrastructure construction is possible to cut the local connections and marginalize the low-class society even further [3]. In splintering-urbanism terms, this phenomenon is called "local-dis-connections".

The facts presented by Graham and Marvin [3] and by Firman [4] have occurred in big cities in Indonesia, for example, is the toll road infrastructure in
Jabodetabek. It is the development of Kota Baru Harapan Indah (KHI) Bekasi that has influenced the development of the area which becomes more exclusive. This development leads to characterization in selecting housing area that portrays social classes and even social gap [5]. Looking at the case on the toll road construction in big cities, its construction in Semarang has different tendencies in which toll road construction in Semarang City functions as the connector for city centers (economic center) thus the symptom of social class differentiation due to this infrastructure construction that occurs in Jabodetabek may also occur in Semarang City. Toll road construction, according to Feng, et al. [6], generally is provided by the government in cooperation with the private sector. One example of a toll road construction project in Indonesia is the construction of Semarang-Solo toll road that passes Kandangan Village. The construction of Semarang-Solo toll road project has been started since 2009 by Jasa Marga of which total length of the toll road is $75.7 \mathrm{~km}$. This project functions to connect Semarang City and Solo and passes 3 (three) regencies that are Semarang Regency, Boyolali Regency, and Sukoharjo Regency. Mainly, this toll road is to reduce the burden in Solo-Ngawi connecting road. The Semarang - Solo project consists of 5 sections in which 2 (two) of them passes Kandangan Village, Bawen Subdistrict that is Section II Ungaran Bawen with toll road

\footnotetext{
* Corresponding author: sariffuddin@live.undip.ac.id
} 
length $11.3 \mathrm{~km}$ and Section III Bawen - Salatiga with toll road length $17.6 \mathrm{~km}$.

The other side of a toll road construction is the impact on its surrounding physical environment. The most obvious impact is the shift of land use in which green and settlement area are compensated and constructed into a toll road. It needs to note that land use is one of the fundamental variables of which impact and change will influence human life and the physical environment [7]. Therefore, when the land use for housing is changed into other infrastructure, that is a toll road, it may cause the settlement area to be relocated or moved to the other area. This condition will impact on the change of landowner in the area around toll road construction and the local disparity of socio-community. Besides impacting the physical environment, toll road construction will also influence the community social aspect in which the impacted community has to give up their houses to be relocated. They also must move and develop new houses and settlements according to their ability without any interventions from the government or other parties in developing the new settlement. Many aspects are changed when they create their new settlement, both spatially where they must re-build all infrastructure to support their settlement and socially in which they must adapt to their new settlement environment. In the science of sociology, disintegration is defined as the disparity of unity to be small parts separated from one to another [8]. As a result, from the construction of Semarang - Solo toll road, this community must be able to adapt to their new settlement thus the process of disintegration is highly possible to happen.

Socio-spatial, on the other hand, is a connection that is mutually influential in which space will influence and form human activities living in it, as well as the human activities that will create the space according to their activities. As explained by O'Brien [9], socio-spatial is formed by three aspects that are the influence of social and economic activities, spatial activities, and the development of technology that influences the spatial change. Therefore, socio-spatial is highly possible to change due to any occurring trigger, in this case, the trigger to socio-spatial change in Kandangan Village is Semarang - Solo toll road construction. In other words, space can also be meant as the product of human concept, as well as the result of material and social interaction. Thus, any change in land use will influence the structure of human life especially one related to the fulfillment of their life necessities. Therefore, eviction and settlement relocation of the community in Kandangan Village as impacted by the construction of Semarang - Solo toll road both in section II Ungaran Bawen and section III Bawen- Salatiga will influence both in spatial and social aspects. There are two possible impacts from this change whether it leads to improvement or degradation. The community, however, must adapt to their new living area. The development of their settlement is done by the community communally in which the community is responsible to improve the infrastructure such as the construction of road network, drainage network to the construction of clean water piping for the community. It is therefore highly possible that the developed settlement area is an unplanned living area that does not meet the preference of the community in Kandangan Village. According to Simis, et al. [10], the redevelopment of community settlement will impact on the community life quality and later the environment. Therefore, a deeper study to the impacts on socio-spatial change in Kandangan Village especially the local community of Kandangan Village for both the aspects of the change of land use, social aspect and spatial aspect due to the construction on Semarang - Solo toll road that are Section II Ungaran - Bawen and Section III Bawen Salatiga is needed.

\section{Material and Methods}

This research was quantitative research in which research method was used to test the theory of sociospatial disintegration, to present the facts and to statistically describe the characteristics of socio-spatial disintegration experienced by the community of Kandangan Village before and after the toll road construction. Besides, the spatial analysis was also conducted to see the visual change on the pattern of the settlement structure in Kandangan Village before and after the toll road construction. This research used a sample as one of the data sources that were collected using questionnaires and interviews as well as documentation in gathering the primary data.

The study area of this research was Kandangan

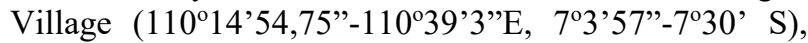
that administratively located in Bawen Sub-district, Semarang District. Kandangan Village is an area that is most impacted area by the toll road construction in Bawen Sub-district since most of its area is occupied and is passed by two constructions at the same time, they are Section II Ungaran-Bawen and Section III BawenSalatiga.

Image interpretation analysis. This analysis was used to see the change in the physical condition of the area from 2011 to 2017 . The data used was the land satellite image of Kandangan Village 2011 and the land satellite image of Kandangan Village 2016. The analysis of the interpretation of the image used tools overlay to see any change in land use.

Housing pattern analysis. The analysis tool used was the nearest neighbor analysis that was by calculating the score of the nearest neighborhood or by using this following formula [11]:

$$
T=\frac{J u}{I h}
$$

where:

$\mathrm{T}=$ the index of nearest neighborhood dispersion

$\mathrm{Ju}=$ average distance calculated from one point to the nearest neighborhood

$\mathrm{Jh}=$ average distance that is totaled when all points have a random pattern

Regression Analysis of Socio-spatial aspects. The function of this analysis was to find out the correlation factor of the defining factors of socio-spatial disintegration in Kandangan Village, Bawen Sub- 
district, therefore an equation formula could be formulated to define the level of socio-spatial disintegration in Kandangan Village.

\section{Results and Discussion}

The study on the socio-spatial change due to the toll road construction in Section III Bawen-Salatiga at Kandangan Village focusing on the aspects contributing to the change of land use and other changes based on social and spatial aspects.

Analysis of Settlement Pattern. According to Darmawan [12], land use is how to manage and to decide the best land function in a land so that the area will have clear functions. Land use in Kandangan Village in 2011 was characterized by plantation land for 525.25 ha, settlement for 144.19 ha, rain-fed rice field for 179.60 ha, and tegalan (dried land that is planted with seasonal plants) with total land 932.43 ha. In 2017, after the toll road construction that was built in steps since 2011, the characteristics of the land use such as plantation, settlement, rice field, and tegalan was changed for toll construction for 35.05 ha. Toll land occupation reached $4 \%$ of the total width of the land in Kandangan Village.

The characteristics of the settlement in Kandangan Village are an unplanned settlement that is the construction from generation to generation. Settlement, according to [13] is constructed based on various elements that are static and dynamic in which static element means the mass of the existing buildings while the dynamic element refers to the road network that connects the spaces. Besides functioning as the connection, the road, based on Oktay [14], is the foundational component of a settlement. Road network as circulation is constructed by the community using government fund and the construction is built based on the topographical condition in Kandangan Village. In 2011, the development of settlement in Kandangan Village was one according to the land topography. This means that the settlement development and the circulation network was developed without planning [15].

Because of the change of the land use, we would like to find out if it caused the change to the settlement in Kandangan Village both before and after the toll road construction. The analysis used ArcGIS with "nearest neighborhood" and was not done manually. The result shows that aggregately Kandangan Village did not undergo any changes to its settlement pattern (see Table 1). Kandangan Village had a cluster pattern and it did not change in 2017 though the NNR (Nearest Neighbor Ratio) had changed from 0.37 to 0.388 . In other words, the settlement became further after the toll road construction.

Socio-Spatial Characteristic in Kandangan Village. Socio-spatial is a term to refer to any human activities that will influence spatial use of which space is influenced by other contributing factors that are social and economic, spatial activity as well as technological development that influence spatial change [9]. Sociospatial in this research used community livelihood assets as the variable and score system to look at the characteristics existing in Kandangan Village (See Table 2).

Table 1. Settlement Pattern in the Focus Area

\begin{tabular}{|l|c|c|c|c|c|c|}
\hline & $\begin{array}{c}\text { Area } \\
\text { (ha) }\end{array}$ & $\begin{array}{c}\text { Land-use } \\
\text { change to be } \\
\text { toll road (\%) }\end{array}$ & $\begin{array}{c}\text { Circulation } \\
\text { pattern }\end{array}$ & $\begin{array}{c}\text { Settlement } \\
\text { Pattern in } \\
2011\end{array}$ & $\begin{array}{c}\text { Settlement } \\
\text { Pattern in 2017 }\end{array}$ & Explanation \\
\hline Dusun Geneng & 9,68 & 28,80 & follow the contours & Random & Clustered & Changed \\
\hline Dusun Pancuran & 12,88 & 3,70 & follow the contours & Clustered & Clustered & Consistent \\
\hline Dusun Deres & 4,56 & 9,03 & follow the contours & Clustered & Clustered & Consistent \\
\hline Dusun Balekambang & 8,13 & 0,10 & follow the contours & Dispersed & Dispersed & Consistent \\
\hline
\end{tabular}

The Socio-spatial analysis was done according to these variables below:

- Social Capital. The result shows that the existing social capital in Kandangan Village has a high score that is 3.96. Regardless of the community movement from their original location. They also acknowledged community organization in their environment and this community organization had an important role in resolving the conflicts emerging in Kandangan Village such as community conflict or infrastructure conflicts caused by toll road construction, such as clean water conflict, mud flood, broken road, and broken irrigation channels

- Human Capital. The result shows that human capital in Kandangan Village has a high level that is 3.60.
Generally, the impacted community by the toll road construction had high capacity and sufficient knowledge, and that they actively involved in managing their settlement area. They were also able to solve their conflict well and helped each other to solve any existing problems.

- Financial Capital. The result shows that Kandangan Village has high financial capital with a score of 3.38. The community indeed underwent occupation shifts after the toll road construction, yet the number was still small, and the community occupation was relatively consistent.

- Natural Resource Capital. The analysis result on the scoring shows that water productivity did not change. The analysis of the score on the natural 
capital in Kandangan Village shows that the village had a moderate level of natural resource capacity which score is 2.65. Generally, the community underwent natural capital changing in which all land owned by the community that was impacted by the toll road was compensated by the toll road constructor.

- Physical Capital. A significant change occurred in Kandangan Village due to the road construction both independently or with the help of the developer in developing the environment and village road. Besides, the community also developed pipe-based clean water cooperation to ease the distribution of clean water to community houses. There were also other changes as impacted by the toll road construction. As a result, Kandangan Village has a high score of physical capital that is 3.32 .

Socio-Spatial Disintegration in Kandangan Village. Land use is a fundamental variable of which impact and change will influence human life and the environment, physically [7]. The land adjustment is highly possible to lead socio-spatial disintegration of settlement. Disintegration may happen in settlement groups into smaller groups that are grouped based on preference, economic level, and land access. The analysis of sociospatial disintegration was conducted by using regression analysis to each variable to see how high it influenced the social-spatial disintegration in Kandangan Village (see figure 1). The regression analysis results on the following formula:

$Y=5,278-0,160 X_{1}-0,219 X_{2}-0,224 X_{3}-0,192 X_{4}-0,163 X_{5}$

The result of the regression model can be used to predict the level of socio-spatial disintegration by inputting the score of each variable $\left(X_{1}=\right.$ modal social, $X_{2}=$ human capital, $\mathrm{X}_{3}=$ financial capital,

Table 2. Characteristic of Socio-Spatial in the Focus Area

\begin{tabular}{|l|c|c|c|c|c|c|c|c|c|c|}
\hline \multirow{2}{*}{$\begin{array}{c}\text { Name of } \\
\text { Dusun }\end{array}$} & \multicolumn{2}{|c|}{ Social Capital } & \multicolumn{2}{c|}{ Human Capital } & \multicolumn{2}{c|}{ Financial Capital } & \multicolumn{2}{c|}{ Natural Capital } & \multicolumn{2}{c|}{ Physical Capital } \\
\cline { 2 - 12 } & Score & Explanation & Score & Explanation & Score & Explanation & Score & Explanation & Score & Explanation \\
\hline Geneng & 4.07 & Very high & 3.66 & High & 3.90 & High & 2.72 & Moderate & 3.13 & High \\
\hline Pancuran & 3.80 & High & 3.49 & High & 3.00 & Moderate & 2.64 & Moderate & 3.22 & High \\
\hline Deres & 3.66 & High & 3.68 & High & 3.33 & High & 2.55 & Moderate & 3.36 & High \\
\hline $\begin{array}{l}\text { Balekam } \\
\text { bang }\end{array}$ & 4.32 & Very High & 3.60 & High & 3.06 & High & 2.64 & Moderate & 3.87 & High \\
\hline
\end{tabular}

$\mathrm{X}_{4}=$ natural capital, $\mathrm{X}_{5}=$ physical capital). After being accumulated, it is found out that the socio-spatial disintegration occurring in Kandangan Village due to the toll road construction is at a moderate level.

Impact of Socio-Spatial Disintegration. According to Johansen [1] toll road is regarded as an effective solution to solve congestion, income distribution, and to increase the gross domestic product of an area. Besides, the construction of toll also aims to the even distribution of development as well as to maintain the balance of area development. On the other hand, this infrastructure development only connects economic centers in an area instead of all areas passed by the toll road [3]. Therefore, toll road construction has other impacts that have to be anticipated. The analysis result shows that Kandangan Village has moderate socio-spatial disintegration. In further identification, the moderate level of socio-spatial disintegration in Kandangan Village had positive impacts both in spatial and non-spatial aspects, as seen in Figure 2 and Table 3.

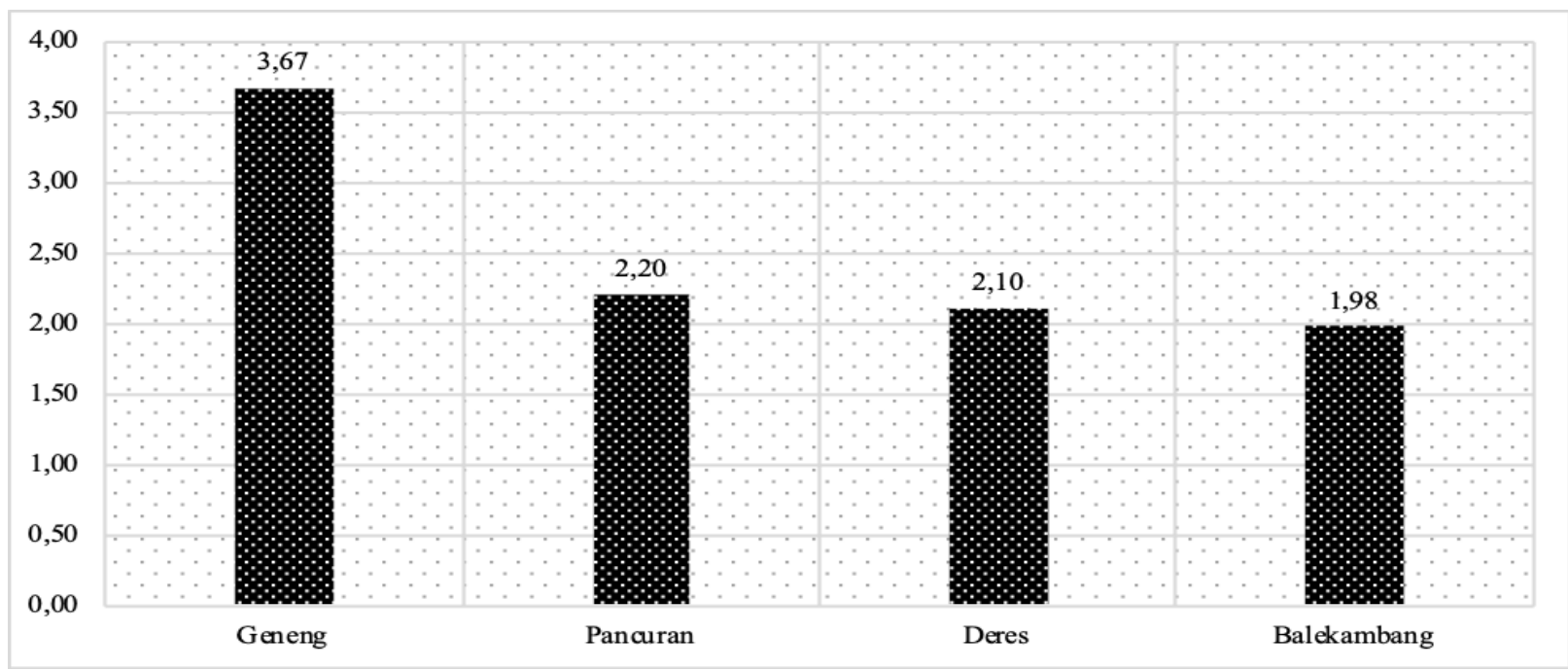

Fig. 1. Level of Socio-Spatial Disintegration in Focus Area 
Table 3. The Impact of Socio-Spatial Disintegration

\begin{tabular}{|c|c|c|}
\hline & Explanation & Types of Impact \\
\hline $\begin{array}{l}\text { Relationship between } \\
\mathrm{SC}^{\mathrm{a}} \& \mathrm{HC}^{\mathrm{b}}\end{array}$ & $\begin{array}{l}\text { The influence of both capitals is social cohesion and high social coordination in } \\
\text { Kandangan Village }\end{array}$ & Socio \\
\hline $\begin{array}{l}\text { Relationship between } \\
\text { HC \& FC }\end{array}$ & $\begin{array}{l}\text { The influence of both capitals is related to the financial capacity post-construction of } \\
\text { a toll road. Where if the financial capital of the community is high then the level of } \\
\text { people's welfare is also high }\end{array}$ & Socio \\
\hline $\begin{array}{l}\text { Relationship between } \\
\mathrm{NC}^{\mathrm{d}} \& \mathrm{FC}^{\mathrm{c}}\end{array}$ & $\begin{array}{l}\text { The influence of both capitals is related to the ability of the community to restore } \\
\text { land resources and land selection in building settlements. }\end{array}$ & Spatial \\
\hline $\begin{array}{l}\text { Relationship between } \\
\mathrm{NC}^{\mathrm{d}} \& \mathrm{PC}^{\mathrm{e}}\end{array}$ & $\begin{array}{l}\text { The influence of both capitals is related to the availability of land for the construction } \\
\text { of infrastructure facilities supporting the settlement }\end{array}$ & Spatial \\
\hline $\begin{array}{l}\text { Relationship between } \\
\mathrm{PC}^{\mathrm{e}} \& \mathrm{SC}^{\mathrm{a}}\end{array}$ & $\begin{array}{l}\text { The influence of both capitals is related to the willingness of community } \\
\text { organizations to manage and build the infrastructure of settlements, and the } \\
\text { willingness of community organizations in resolving the infrastructure conflict. }\end{array}$ & Socio \\
\hline $\begin{array}{l}\text { Relationship between } \\
\mathrm{SC}^{\mathrm{a}} \& \mathrm{FC}^{\mathrm{c}}\end{array}$ & $\begin{array}{l}\text { The influence of both capitals is related to the type of work and the capacity of } \\
\text { community financing to the monthly fee for the services of mass organizations }\end{array}$ & Socio \\
\hline $\begin{array}{l}\text { Relationship between } \\
\mathrm{NC}^{\mathrm{d}} \& \mathrm{SC}^{\mathrm{a}}\end{array}$ & $\begin{array}{l}\text { The influence of these two modalities is related to the role of community } \\
\text { organizations in addressing natural resource conflicts }\end{array}$ & Socio \\
\hline $\begin{array}{l}\text { Relationship between } \\
\mathrm{PC}^{\mathrm{e}} \& \mathrm{FC}^{\mathrm{c}}\end{array}$ & $\begin{array}{l}\text { The influence of both capitals is related to the financing capacity of the community } \\
\text { affected by the toll road to public infrastructure }\end{array}$ & Spatial \\
\hline $\begin{array}{l}\text { Relationship between } \\
\mathrm{PC}^{\mathrm{e}} \& \mathrm{HC}^{\mathrm{b}}\end{array}$ & $\begin{array}{l}\text { The influence of these two modalities is related to individual roles, individual } \\
\text { sadness, and individual responsibility in managing and maintaining public } \\
\text { infrastructure }\end{array}$ & Socio \\
\hline $\begin{array}{l}\text { Relationship between } \\
\mathrm{NC}^{\mathrm{d}} \& \mathrm{HC}^{\mathrm{b}}\end{array}$ & $\begin{array}{l}\text { The influence of both capitals is related to the selection of land to be built home for } \\
\text { people affected by toll roads }\end{array}$ & Spatial \\
\hline
\end{tabular}

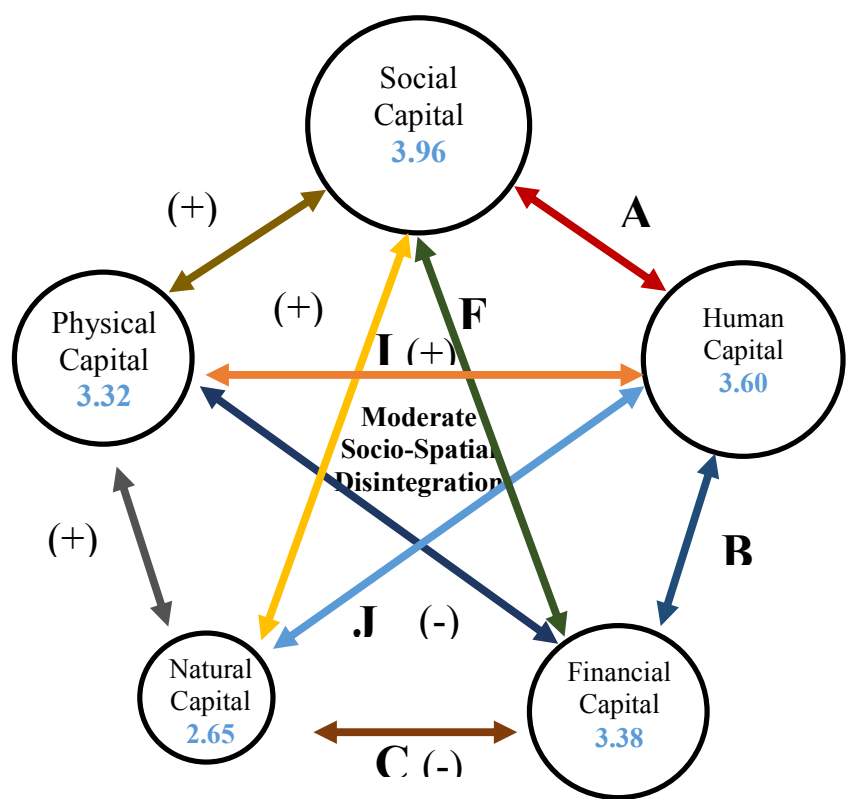

Fig. 2. The level of socio-spatial disintegration in the focus area

\section{Conclusion}

After analyzing the level of socio-spatial disintegration in Kandangan Village and reviewing the literature as the source for this research, what O'Brien [9] explains is proven that space is constructed by 3 (three) aspects that are the influence of social and economic activity, spatial activity, and technology development which then influence the spatial change. After the analysis of the settlement pattern and circulation pattern in Kandangan Village impacted by Semarang-Solo toll road construction, Kandangan Village had its space changed due to the social activities and technology development (that is the road construction) that changed the face of Kandangan Village from 2011 until 2017. Both opinions from Natarajan [16] about space and community that mutually developing, influencing, and forming was proven to happen in Kandangan Village. That the 
construction of Semarang-Solo toll road built by the government in Section II and Section III as spatial activity had influenced the community life in Kandangan Village by changing their life aspects as seen in the 5 (five) capitals that were social capital, human capital, financial capital, natural resource capital, and physical capital.

Spatial and social aspects are indeed inseparable from one to the other. The change of both aspects in Kandangan Village had led the disintegration of which impacts were experienced by the community. It was true, however, that the impact of socio-spatial disintegration due to the toll construction was not all negative; there were also positive impacts. The negative impacts experienced by the community due to the toll road construction was the reduced social relationship among the community since the emergence of conflicts both community conflict and infrastructure conflict such as broken road, toll road complaints, to mud flood and crop failure which by the community were regarded as the negative impacts from the toll road construction. These problems, however, did not divide the community as proven by the high level of cohesion and social coordination in Kandangan Village as well as the role of social organization in resolving the conflicts also their willingness to work together in redeveloping their settlement. Besides the negative impacts, the toll road construction also gave positive impacts that were the growth of the settlement and the development of settlement infrastructure in Kandangan Village, for example, the road network in some locations that had better condition after the construction, clean water network that was distributed smoothly, and that indeed the community took benefit from the compensation they received for a business capital to improve their life quality and family welfare Last, Graham and Marvin [3] "local-dis-connections" was not completely proven that in Kandangan Village there was no marginalization of the low-level community due to the construction. The community still lived well since basically, they had social capital that was the strong cohesion and coordination. Even though there were some changes after the toll road construction and that there was a moderate level of socio-spatial disintegration, it did not lead to huge conflict that divided the community. Until this time, the community lives comfortably as they have had it before.

\section{Acknowledgments}

This research was supported by Commitment (http://commuterinitiative.org/) that aids in all financial issues. This research is also supported by Dr. Asnawi Manaf \& Mrs. Bitta Pigawati, MT that has guided and directions so that this research can be well conducted.

\section{References}

1. F. Johansen, Toll road characteristics and toll road experience in selected South East Asia countries,
Transportation Research Part A: General, 23, 463466 (1989)

2. H. Chung, Some socio-economic impacts of toll roads in rural China, Journal of Transport Geography, 10, 145-156 (2002)

3. S. Graham and S. Marvin, Splintering urbanism: networked infrastructures, technological mobilities and the urban condition: Routledge, (2002)

4. T. Firman, New town development in Jakarta Metropolitan Region: a perspective of spatial segregation, Habitat International, 28, 349-368 (2004)

5. A. Diningrat, Segregasi Spasial Perumahan Skala Besar: Studi Kasus Kota Baru Kota Harapan Indah (KHI) Bekasi, Jurnal Perencanaan Wilayah dan Kota, 26, 111-129 (2015)

6. Z. Feng, S.-B. Zhang, and Y. Gao, Modeling the impact of government guarantees on toll charge, road quality and capacity for Build-OperateTransfer (BOT) road projects, Transportation Research Part A: Policy and Practice, 78, 54-67 (2015)

7. M. Ali, S. Hadi, and B. Sulistyantara, Study on Land Cover Change of Ciliwung Downstream Watershed with Spatial Dynamic Approach, Procedia - Social and Behavioral Sciences, 227, 52-59 (2016)

8. S. Aminah, Konflik dan Kontestasi Penataan Ruang Kota Surabaya, Masyarakat: Jurnal Sosiologi, 20, 59-79, (2015)

9. J. O'Brien, Shaping Knowledge: Complex Sociospatial Modelling for Adaptive Organizations: Elsevier (2014)

10. M. Simis, A. Awang, and K. Arifin, From Exlandfill to Public Park: Impact on Local Community's Quality of Life and Living Environment, Procedia - Social and Behavioral Sciences, 222, 763-771 (2016)

11. P. Haggett, Geography-a modern synthesis: Ulmer, (1991)

12. E. Darmawan, Teori dan Implementasi Perancangan Kota. Semarang: Penerbit Undip (2003)

13. R. Krier, Urban Space. New York: Rizzoli International Publications (1995)

14. D. Oktay, The quest for urban identity in the changing context of the city: Northern Cyprus, Cities, 19, 261-271 (2002)

15. R. Flores-Fernandez, Physical and Spatial Characteristics of Slum Territories-Vulnerable to Natural Disasters, in Slum Upgrading Programmes in Nairobi Challenges In Implementation, R. A. F. Fernandez, S. Owuor, A. Desgroppes, and N. Mung'ala, Eds., ed. Nairobi: IFRA: Institut Fraincais de Recherce on Afrique, p. 5 (2011)

16. L. Natarajan, Socio-spatial learning: A case study of community knowledge in participatory spatial planning, Progress in Planning, 111, 1-23 (2017) 